\title{
Trophic segregation of Falkland Islands seabirds: insights from stable isotope analysis
}

\author{
Felix Weiss - Robert W. Furness - Rona A. R. McGill • \\ Ian J. Strange · Juan F. Masello $\cdot$ Petra Quillfeldt
}

Received: 19 February 2009/Revised: 16 June 2009/Accepted: 19 June 2009/Published online: 7 July 2009

(C) The Author(s) 2009. This article is published with open access at Springerlink.com

\begin{abstract}
Seabird colonies provide rare opportunities to study trophic segregation in an entire bird community. We here present data on nitrogen and carbon isotope ratios of eight species of seabirds from New Island, Falkland Islands, and compare trophic levels (TL) and foraging distributions. We included adult feathers representing the interbreeding season, as well as chick feathers or down representing the breeding season. The stable isotope ratios indicated differences in feeding areas and TLs between species, consistent with the data of previous conventional diet analyses and observations at sea. We further reviewed conventional and stable isotope seabird community studies calculating the means and ranges of TLs observed across these studies. The mean TL (3.7) of the seabird community on New Island was at the lower end of the mean value range (3.5-4.5), but not significantly different, from the reviewed seabird communities. Seabirds on New Island had a range of $1.3 \mathrm{TLs}$, which is on the upper end of ranges within a community (0.4-1.5), indicating strong trophic structuring.
\end{abstract}

F. Weiss · J. F. Masello · P. Quillfeldt ( $ه)$

Max-Planck-Institut für Ornithologie, Vogelwarte Radolfzell,

Schlossallee 2, 78315 Radolfzell, Germany

e-mail: petra.quillfeldt@gmx.de

R. W. Furness

Faculty of Biomedical and Life Sciences, Graham Kerr Building, University of Glasgow, Glasgow G12 8QQ, UK

R. A. R. McGill

NERC Life Sciences Mass Spectrometry Facility, Scottish

Universities Environmental Research Centre,

East Kilbride, Glasgow G75 0QF, UK

I. J. Strange

New Island Conservation Trust, The Dolphins,

Stanley, Falkland Islands
Keywords Stable isotopes - Seabird colonies ·

Trophic level · Falkland Islands · Dietary segregation

\section{Introduction}

Seabird colonies have become a focus of international conservation due to the increasing interaction with fisheries, high mortality rates related to anthropogenic activity and vulnerability to climate change (Thompson 1989; Barton 2002; Hilton et al. 2006). The correct interpretation of long-term population-trends depends not only on a good knowledge of the breeding and foraging biology of the species, but also on additional monitoring of diet. Classical methods of diet analysis such as stomach flushing, dissection and pellet analysis (Barret et al. 2007) have been extensively applied to seabirds in various colonies (Wanless et al. 1992; Croxall et al. 1997; Cherel et al. 2002; Clausen and Pütz 2002). However, those methods are biased against easily digested prey (Hobson et al. 1994) and can be stressful for the birds or require dead birds. In addition, these conventional methods are often difficult to apply during the interbreeding season (but see Jackson 1988), diet analysis can be very time-consuming and sampling can be restricted by the need to transport stomach contents frozen or in ethanol.

Stable isotope ratios of bird tissues and prey organisms can be used to overcome these problems (Hobson et al. 1994; Post 2002; Fry 2006), and can be applied to complement other available methods. The stable nitrogen isotope ${ }^{15} \mathrm{~N}$ is enriched relative to ${ }^{14} \mathrm{~N}$ in a predictable manner with each trophic level (TL), providing a tool to estimate TLs (Post 2002). Due to different turnover times, different tissues integrate diet over more or less time, thereby buffering fluctuations in the diet (Ogden et al. 2004). As the 
isotope value of the feathers remains unchanged after they are grown, feathers provide a tool to study diet during the moulting period, which procellariiform seabirds usually spend at sea (Cherel et al. 2000a). The heavy isotope of carbon ${ }^{13} \mathrm{C}$ is only slightly enriched (in relation to ${ }^{12} \mathrm{C}$ ) with each trophic step, providing little information about TL (Hobson and Welch 1992; Post 2002). However, it is a good tracer of feeding areas in the southwest Atlantic, as it changes with latitude (Quillfeldt et al. 2005; Cherel and Hobson 2007). Carbon isotope ratios are lower in waters south of the Antarctic Convergence. In addition, carbon isotope ratios are higher in areas of high productivity and lower in pelagic phytoplankton than in benthic and inshore phytoplankton (Francois et al. 1993; Hobson et al. 1994; Quillfeldt et al. 2005; Cherel and Hobson 2007) and these factors can result in variations that overprint the linear latitude-related effect.

The diet of several seabird species of New Island, Falkland Islands, has been studied on two occasions using conventional methods (Thompson 1989; Clausen and Pütz 2002). The aim of the present study was to quantify trophic segregation within the seabird community, as reflected in stable isotope ratios, and to compare TLs with recent studies on diet composition on New Island and with other colonies.

\section{Methods}

Species and study site

Samples were collected as part of an ongoing study at New Island Nature Reserve, Falkland Islands $\left(51^{\circ} 43^{\prime} \mathrm{S}\right.$, $61^{\circ} 17^{\prime}$ W; e.g., Quillfeldt et al. 2003, 2006, 2007a, b, c, 2008a, b, c, d) during three consecutive breeding seasons (2003/2004, 2004/2005, 2005/2006). New Island is recognised as an important bird area for its seabird colonies of 13 different species. The seabird community comprises 4(3) species of penguins, 1(1) albatross, 3(2) petrels, 2(1) cormorants, 1(0) skua and 2(1) gulls (in parentheses the number of species here studied). The weaker western branch of the Falkland Current produces a productive area of upwelling west of New Island (Fig. 1, oceanography reviewed by Upton and Shaw 2002; Glorioso 2002).

\section{Sampling}

We included samples representing the interbreeding season (adult feathers), as well as the breeding season (chick feathers or down where available). A total of 170 samples from eight species of seabirds were collected (Table 1). Feathers from albatrosses, petrels, prions, cormorants and gulls were collected non-invasively from birds during the

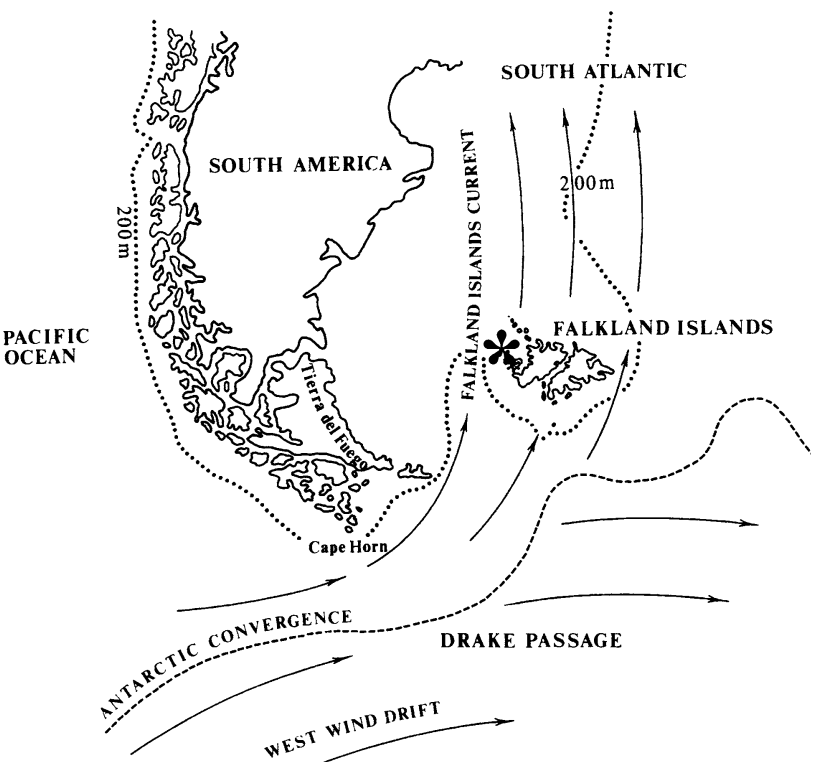

Fig. 1 Map of the study area. New Island is marked with a star

breeding season, by checking the area around breeding colonies for remains and moulted feathers. Feathers from penguins were collected during moult from the ground in front of individual burrows (Magellanic penguins Spheniscus magellanicus) or around moulting groups of rockhopper-Eudyptes chrysocome and gentoo penguins Pygoscelis papua. We cannot rule out completely that two moulted feathers of penguins are from the same bird but it is highly unlikely because several hundred to thousand birds moult in a group and we have collected a single feather from each site, with a minimum distance of $20 \mathrm{~m}$ between collection sites. Chick down from thin-billed prions Pachyptila belcheri and black-browed albatross Thalassarche melanophrys was collected during the time of natural shedding of these feathers, by gently pulling a small amount of down off the tips of the contour feathers to which they were attached. Down feathers of penguins were collected from remains of chicks killed by skuas. All feathers except the penguin feathers were clearly distinguished by size and colour. The three penguin species breed and moult in very different places, e.g., Magellanic penguins in their burrows where they also moult. Thus, feathers were collected at the burrow entrances. Gentoo penguins have two large colonies, each with several subcolonies, on two plains at New Island. They return to these colonies to moult. Finally, rockhopper penguins breed and moult at three colonies on rock cliffs at New Island, and we collected feathers there, during the moulting time.

The Falkland Islands Fisheries Department kindly provided samples obtained during a survey cruise in February 2006 by bottom and plankton trawling close to the Falkland Islands (P. Brickle, personal communication). The samples 
Table 1 Stable isotope ratios and calculated TLs of seabirds from New Island

\begin{tabular}{|c|c|c|c|c|c|c|c|}
\hline Species & Tissue & $\delta^{13} \mathrm{C}(\%)$ & SE & $\delta^{15} \mathrm{~N}(\% 0)$ & SE & $\mathrm{TL}$ & $n$ \\
\hline $\mathrm{GEPE}^{\mathrm{a}, \mathrm{b}}$ & Feathers & -16.26 & 0.10 & 15.88 & 0.24 & 3.7 & 13 \\
\hline GEPE $^{a}$ & Down & -17.20 & 0.14 & 14.09 & 0.02 & 3.2 & 2 \\
\hline $\mathrm{ROPE}^{\mathrm{c}}$ & Feathers & -16.65 & 0.46 & 14.03 & 0.39 & 3.2 & 6 \\
\hline $\mathrm{ROPE}^{\mathrm{c}}$ & Down & -15.85 & 0.09 & 13.56 & 0.19 & 3.0 & 5 \\
\hline MAPE $^{a, b, c}$ & Feathers & -16.96 & 0.57 & 15.50 & 0.49 & 3.6 & 11 \\
\hline BBAL $^{a, c}$ & Feathers & -15.98 & 0.19 & 16.88 & 0.25 & 4.0 & 10 \\
\hline BBAL $^{a, c}$ & Down & -16.44 & 0.10 & 16.17 & 0.17 & 3.8 & 12 \\
\hline $\mathrm{TBPR}^{\mathrm{b}, \mathrm{c}}$ & Feathers & -24.04 & 0.23 & 8.32 & 0.26 & & 62 \\
\hline $\mathrm{TBPR}^{\mathrm{b}, \mathrm{c}}$ & Down & -18.50 & 0.15 & 12.10 & 0.17 & & 27 \\
\hline $\mathrm{WCPE}^{\mathrm{c}}$ & Feathers & -15.44 & 0.49 & 18.38 & 0.69 & 4.4 & 5 \\
\hline $\mathrm{WCPE}^{\mathrm{c}}$ & Down & -18.57 & 1.01 & 15.45 & 0.61 & 3.6 & 3 \\
\hline $\mathrm{IMCO}^{\mathrm{c}}$ & Feathers & -15.38 & 0.39 & 16.05 & 0.11 & 3.8 & 7 \\
\hline DOGU $^{\mathrm{b}}$ & Feathers & -16.37 & 0.18 & 13.90 & 0.17 & 3.1 & 6 \\
\hline
\end{tabular}

All feather samples are from adult birds, all down samples are from chicks

GEPE gentoo penguin Pygoscelis papua, ROPE rockhopper penguin Eudyptes chrysocome, MAPE Magellanic penguin Spheniscus magellanicus, BBAL black-browed albatross Thalassarche melanophrys, $T B P R$ thin-billed prion Pachyptila belcheri, WCPE white-chinned petrel Procellaria aequinoctialis, IMCO imperial cormorant Phalacrocorax atriceps, DOGU dolphin gull Larus scoresbii

${ }^{\text {a }}$ Breeding season 2003/2004

b Breeding season 2004/2005

${ }^{c}$ Breeding season 2005/2006

included fish muscle from southern blue whiting Micromesistius australis $(n=2$, length $470-560 \mathrm{~mm})$, hoki Macruronus magellanicus ( $n=4$, length $270-380 \mathrm{~mm}$ ), pike icefish Champsocephalus esox $(n=4$, length 170 $310 \mathrm{~mm}$ ), yellowfin rockcod Patagonotothen guntheri ( $n=4$, length $150-160 \mathrm{~mm})$ and Patagonian rockcod Patagonotothen ramsayi ( $n=4$, length $230-280 \mathrm{~mm}$ ), squid muscle samples of Argentine shortfin squid Illex argentinus $(n=4$, length $165 \mathrm{~mm})$, great hooked squid Moroteuthis ingens $(n=4$, length $180-230 \mathrm{~mm})$ and Patagonian longfin squid Loligo gahi $(n=4$, length $125-250 \mathrm{~mm}$ ), as well as crustaceans (whole exemplars of krill Euphausia lucens and Thysanoessa macrura, lobster krill Munida gregaria and amphipods Themisto gaudichaudii). The stable isotope data of these samples are given in the appendices of Quillfeldt et al. (2008a). All of these species are particularly abundant representatives for crustaceans, squid and fish species around the Falkland Islands and are known from conventional diet analysis to be of great importance to the seabirds breeding on New Island (Thompson 1989). Some of the taxa are also important commercial species, especially Lolligo gahi, Ilex argentinus and Micromesistius australis (Agnew 2002).
Sample preparation and stable isotope analysis

Feather tips and down were cut into small pieces with stainless steel scissors. Lipids were not washed off the feathers as they were shown to have negligible effects on the isotope ratios (Mizutani et al. 1992).

Lipids were extracted from all fish, squid and crustacean samples, to control for differences in lipid content (Bearhop et al. 2002), using a Soxhlet apparatus with a methanol:chloroform 2:1 solvent. Following extraction, the samples were dried under a fume hood for at least $12 \mathrm{~h}$ and ground to a homogeneous fine powder with mortar and pestle.

Sub-samples of crustaceans were acid-washed with $\mathrm{HCl}$ after lipid extraction to remove inorganic carbonates (Carabel et al. 2006). Acid-washed sub-samples were used to determine the carbon isotope ratios of crustaceans.

Sub-samples of $0.7 \mathrm{mg}$ were loaded in tin-cups for stable isotope analysis. Carbon and nitrogen isotope ratios were measured by continuous-flow isotope ratio mass spectrometry using a Costech Elemental Analyser linked to a Thermo Finnigan Delta Plus XP Mass Spectrometer. Carbon and nitrogen isotope ratios were determined simultaneously for feathers, but all tissues which had undergone lipid extraction and acid washing were analysed as two separate aliquots: untreated for nitrogen and treated tissue for carbon. Two laboratory standards were analysed for every 10 unknown samples, allowing any instrumental drift over a typical $14 \mathrm{~h}$ run to be corrected. Stable isotope ratios were expressed in $\delta$ notation as parts per thousand (\%) deviation from the international standards V-Pee dee belemnite (carbon) and AIR (nitrogen), according to the following equation $\delta Y=\left(R_{\text {sample }} \times R_{\text {standard }}^{-1}-1\right) \times$ 1,000 where $Y$ is ${ }^{15} \mathrm{~N}$ or ${ }^{13} \mathrm{C}$ and $R$ is the corresponding ratio ${ }^{15} \mathrm{~N} /{ }^{14} \mathrm{~N}$ or ${ }^{13} \mathrm{C} /{ }^{12} \mathrm{C}$. Measurement precision of both $\delta^{15} \mathrm{~N}$ and $\delta^{13} \mathrm{C}$ was better than $0.3 \%$.

\section{Calculation of trophic levels}

Animal tissues are enriched in ${ }^{15} \mathrm{~N}$ compared to their diet (Mizutani et al. 1992; Post 2002; Fry 2006). The mean enrichment factor across various taxa in 56 studies was $3.4 \% \pm 0.98$ SD (Post 2002). The fractionation factor from diet to bird feathers is greater. The physiological principals causing the higher enrichment factor from diet to feather compared to from diet to blood or from diet to muscle tissue are not studied in most species, but higher enrichment factor from diet to feather is observed in various species including garden warbler Sylvia borin (Hobson and Bairlein 2003), white ibis Eudocimus albus and cormorant Phalacrocorax carbo (Mizutani et al. 1992). For penguins it is suspected, that this is due to the mobilisation of internal stores during moult (Cherel et al. 2005a; 
Quillfeldt et al. 2008b). The mean enrichment factor in 20 controlled feeding experiments was 4.0\% $\pm 1.2 \mathrm{SD}$ (Cherel et al. 2005b), and paired differences in $\delta^{15} \mathrm{~N}$ of simultaneously grown feathers and blood cells of procellariiform seabirds were around 1.0\%o (Quillfeldt et al. 2008b). The TL of an animal (TLa) can be calculated in systems with only one primary producer by comparing its $\delta^{15} \mathrm{~N}$ value (SIa) with that of another taxon (SIb) of known TL (TLb) assuming an average enrichment of 3.4\%o (Post 2002):

$\mathrm{TLa}=\mathrm{TLb}+(\mathrm{SIa}-\mathrm{SIb}) \times 3.4 \%^{-1}$

To include the different fractionation factor for feathers (SIc) we subtracted SIc from the difference between SIa and SIb and added 1 to the trophic level of the reference species (TLb)

$\mathrm{TLa}=\mathrm{TLb}+1+($ SIa--SIb--SIc $) \times 3.4 \%{ }^{-1}$

The TLs of birds (except adult thin-billed prions), fish and squid in the present study were calculated relative to nitrogen isotope ratios of Euphausia lucens and Thysanoessa macrura (mean $\delta^{15} \mathrm{~N}$ of both species was $10.51 \%$ ) with an estimated TL of 2.3 [determined for E. superba (Hodum and Hobson 2000)]. Euphausids are ideally suited as reference species because they are relatively long-lived compared to other species of zooplankton and feed largely on phytoplankton, thereby buffering possible fluctuations of isotope ratios in the phytoplankton (Sommer 1998; Post 2002). Several individuals were pooled in the samples of E. lucens and T. macrura to obtain a reliable average reference value.

Comparison with other studies

Several studies on trophic relationships in seabird colonies have been published, but the methods vary from study to study, especially the choice of tissue from the birds (muscle, liver, whole blood, egg albumen or feather), reference species for defining trophic levels [particulate organic matter (POM), euphausids, Engraulis anchoita (fish), Calanus hyperboreus (amphipod) or Mallotus villosus (fish)] and fractionation factor (2.4-3.3) (Thompson 1989; Hobson and Welch 1992; Rau et al. 1992; Hobson et al. 1994; Sydeman et al. 1997; Hobson et al. 2002; Forero et al. 2004). Therefore, we calculated new TLs from the published $\delta^{15} \mathrm{~N}$ values with a consistent model (Eq. 2). SIc was varied depending on the tissue: pectoral muscle $3.1 \%$, whole blood $2.9 \%$, liver 4.0\% , feather 4.0\% (Ogden et al. 2004), and for egg albumen we used a discrimination factor of 3.1\% (Sydeman et al. 1997). For TLb and SIa we choose published values for reference species from each study (Table 4). We also compared isotope ratios with results from conventional diet studies for all seabirds in this study. From the published isotope ratios TLs were calculated with the model described above.

Data analysis

Data analysis was carried out using SPSS 11.0. The isotopic ratios were compared between groups using discriminant analysis (Wilk's $\lambda$ ) with carbon and nitrogen isotope ratios as dependent variables in order to detect overall differences based on both carbon and nitrogen isotope ratios. If overall differences were detected, $\delta^{15} \mathrm{~N}$ and $\delta^{13} \mathrm{C}$ values were compared separately by one-way ANOVA, and Tukey post hoc tests. The TLs of seabird communities were compared with ANOVA and Tukey post hoc tests.

\section{Results}

Prey type isotope ratios and trophic levels

Fish, squid and crustaceans collected in the vicinity of the Falkland Islands had distinct isotope ratios (Figs. 2, 3, Wilk's $\lambda=0.31, P<0.001)$. Differences among the three groups were clearest in $\delta^{15} \mathrm{~N}$ values (ANOVA: $\left.F_{34,2}=22.4, P<0.001\right)$, where all pairwise comparisons (Tukey post hoc tests) were significant. There was also an overall difference between fish, squid and crustaceans in $\delta^{13} \mathrm{C}$ values (ANOVA: $F_{34,2}=5.5, P=0.008$ ), where crustaceans had lower $\delta^{13} \mathrm{C}$, while squid and fish had similar $\delta^{13} \mathrm{C}$ (Tukey post hoc tests). The calculated TLs of fish ranged over 0.6 TL (mean 3.1, SE 0.1, min 2.8, max 3.4), squid ranged over $0.7 \mathrm{TL}$ (mean 2.3, SE 0.2, min 1.9, $\max 2.6$ ) and crustaceans ranged over 1.3 TL (mean 2.0, SE $0.2, \min 1.1, \max 2.4$ ).

Seabird isotope ratios and trophic levels

The feathers of adult seabirds differed in isotope values between species (Wilk's $\lambda=0.330, P<0.001$ ), both in $\delta^{13} \mathrm{C}$ (ANOVA: $\left.F_{7,113}=113.9, P<0.001\right)$ and $\delta^{15} \mathrm{~N}$ $\left(F_{7,113}=64.2, P<0.001\right)$. Samples of adult thin-billed prions were separated by significantly lower $\delta^{13} \mathrm{C}$ and $\delta^{15} \mathrm{~N}$ values than all other groups (Tukey post hoc tests, Table 1, Fig. 3) and showed a wide range of values both in $\delta^{13} \mathrm{C}$ $\left(\min -28.07 \%\right.$, $\max -18.27 \%$ ) and $\delta^{15} \mathrm{~N}(\min 5.93 \%$, $\max 17.04 \%$ ). When thin-billed prions were excluded from the analysis, there was only a slight difference between species in $\delta^{13} \mathrm{C}\left(F_{6,52}=2.7, P=0.024\right)$, as Magellanic penguins and imperial cormorants differed in $\delta^{13} \mathrm{C}$ according to Tukey post hoc tests $(P=0.025)$.

When thin-billed prions were excluded, the feathers of adults of the remaining seabird species still differed in their 


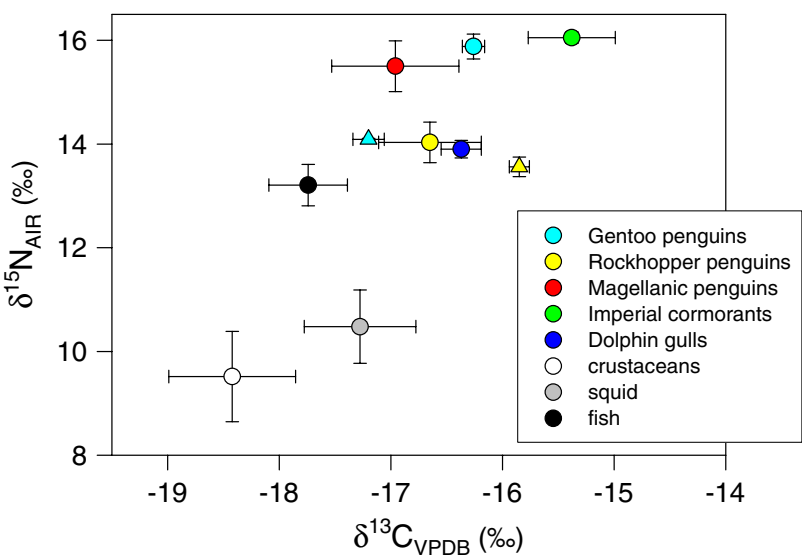

Fig. 2 Isotope ratios of penguins, imperial cormorants, dolphin gulls and prey classes (mean \pm SE). Adult feathers, which are grown in the interbreeding period, are marked with circles. Chick down feathers, which are grown in the breeding season, are given in triangles

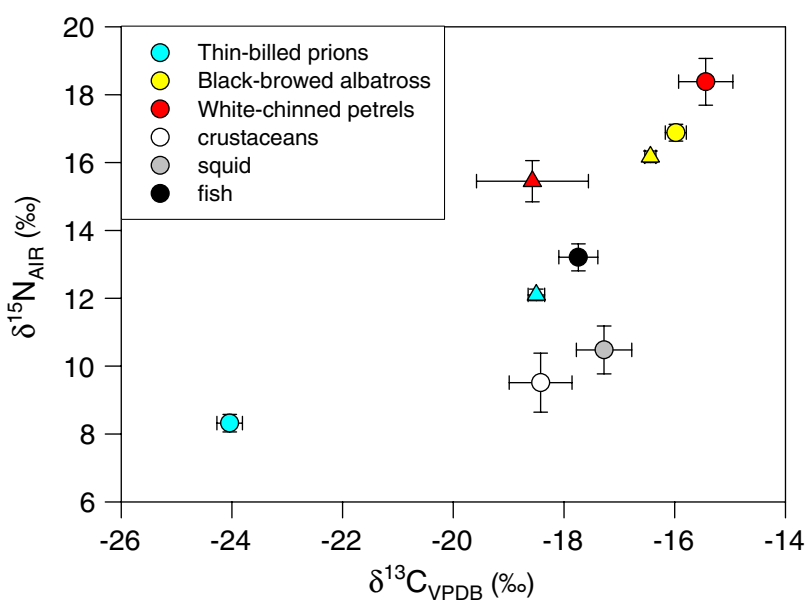

Fig. 3 Isotope ratios of procellariiform seabirds and prey classes (mean $\pm \mathrm{SE}$ ). Adult feathers, which are grown in the interbreeding period, are marked with circles. Chick down feathers, which are grown in the breeding season, are given in triangles

$\delta^{15} \mathrm{~N}$ values $\left(F_{6,52}=5.1, P<0.001\right)$, with the highest values observed in white-chinned petrels and black-browed albatross, and the lowest values for dolphin gulls (Fig. 4; Table 1).

Adults of the three penguin species differed in their isotope signatures (Fig. 2, Wilk's $\lambda=0.068, P=0.037$ ), and this was due to differences in $\delta^{15} \mathrm{~N}\left(F_{2,27}=4.9\right.$, $P=0.016)$. Post hoc tests identified rockhopper penguins as different in $\delta^{15} \mathrm{~N}$ from the other two species (Tukey, $P=0.012)$. Adults of the three penguin species had similar $\delta^{13} \mathrm{C}$ (ANOVA: $F_{2,27}=0.9, P=0.410$ ).

Differences between adults and chicks were tested for five species. The significance level was adjusted to $P=0.01$ according to Bonferroni. Compared with adults, gentoo penguin chicks had significantly lower $\delta^{13} \mathrm{C}$ values

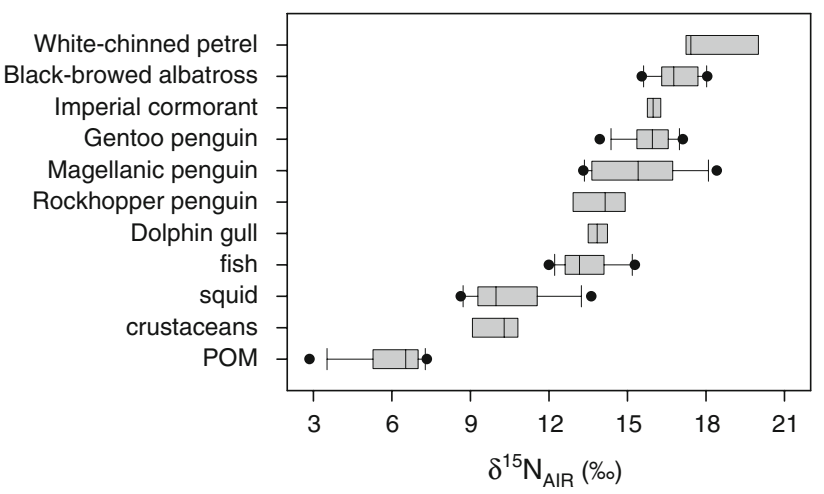

Fig. 4 Nitrogen stable isotope ratios of seabirds (adult feathers) and prey species categories. The grey area encloses the second and third quartiles. Black bars depict the first and fourth quartile. Outlying data are indicated by black dots. Thin-billed prions were omitted because of the different baseline isotope value due to their southern distribution

( $t$ test: $t=3.5$, df $13, P=0.004$ ) and non-significantly lower $\delta^{15} \mathrm{~N}$ values ( $t$ test: $\left.t=2.8, d f 13, P=0.014\right)$. In thin-billed prions, the opposite was observed, as feathers of adults were significantly depleted in ${ }^{13} \mathrm{C}$ and ${ }^{15} \mathrm{~N}$ compared to down feathers of chicks (Fig. 3, $\delta^{13} \mathrm{C}: t=15.3, d f 87$, $P<0.001 ; \delta^{15} \mathrm{~N}: t=9.2$, df $\left.87, P<0.001\right)$. The isotope ratios of black-browed albatrosses (Fig. $3, \delta^{13} \mathrm{C}: t=2.2, d f$ $20, P=0.036 ; \delta^{15} \mathrm{~N}: t=2.4$, df $20, P=0.026$ ), whitechinned petrels (Fig. 3, $\delta^{13} \mathrm{C}: t=3.2, d f 6, P=0.019$; $\left.\delta^{15} \mathrm{~N}: t=2.9, d f 6, P=0.029\right)$ and rockhopper penguin chick feathers did not differ statistically from those of adults $\left(\delta^{13} \mathrm{C}: t=1.6 d f 9, P=0.155 ; \delta^{15} \mathrm{~N}: t=1.0 d f 9\right.$, $P=0.338$ ).

The calculated TLs of adult seabirds ranged over $1.3 \mathrm{TL}$ (from 3.1 for dolphin gulls to 4.4 for white-chinned petrels, Table 1). Compared to seabird communities studied earlier (Table 2), the mean TL of 3.7 of the seabird community on New Island (excluding thin-billed prions, see Discussion) was at the lower end of the mean value range (3.5-4.5), but not significantly different, from other seabird communities. Seabirds at New Island had a range of $1.3 \mathrm{TL}$, compared to a range of 0.4 to 1.5 as reported in other seabird communities (Table 2).

\section{Discussion}

We use stable isotope signatures of seabirds breeding on New Island to compare their trophic position and distribution during foraging. The stable isotope signatures indicated a range of trophic positions, from low levels in scavenging dolphin gulls and in rockhopper penguins to high levels, especially in black-browed albatross and white-chinned petrels (Fig. 4). 
Table 2 Trophic studies of seabird colonies

\begin{tabular}{lllllll}
\hline $\begin{array}{l}\text { Mean } \\
\text { TL }\end{array}$ & Min & Max & Range & Tukey Reference \\
\hline 3.6 & 3.1 & 4.4 & 1.3 & 7 & a, b, c & This study \\
4.1 & 4.0 & 4.5 & 0.5 & 5 & a, c & $\begin{array}{l}\text { Hobson and Welch } \\
(1992)\end{array}$ \\
3.6 & 3.4 & 3.9 & 0.6 & $6^{\mathrm{a}}$ & a, b & Hobson et al. (1994 \\
3.5 & 3.0 & 4.4 & 1.5 & $19^{\mathrm{b}}$ & $\mathrm{b}$ & Hobson et al. (1994) \\
4.0 & 3.4 & 4.4 & 1.0 & 7 & a, b, c & Sydeman et al. (1997) \\
3.8 & 3.1 & 4.5 & 1.4 & 7 & a, b, c & Hobson et al. (2002) \\
4.1 & 3.4 & 4.6 & 1.2 & 15 & c & Forero et al. (2004) \\
3.6 & 3.2 & 4.2 & 1.0 & 12 & a, b & Rau et al. (1992) \\
3.8 & 3.4 & 4.0 & 0.6 & $6^{\mathrm{c}}$ & a, b, c & Thompson et al. (1999) \\
3.6 & 3.4 & 3.8 & 0.4 & $6^{\text {d }}$ & a, b, c & Thompson et al. (1999) \\
\hline
\end{tabular}

Note that TLs were recalculated from the published $\delta^{15} \mathrm{~N}$ values, therefore they differ slightly from the TLs published in the original study. The study sites, tissues and reference species were as follows: Barrow Strait-Lancaster Sound, Canada; pectoral muscle; POM $\left(\mathrm{TL}=1, \delta^{15} \mathrm{~N}=5.4 \%\right.$ ) (Hobson and Welch 1992). For the comparison, only adult birds from the present study were considered, thinbilled prions were omitted, because calculated TL for this species possibly underestimated the real TL (see "Discussion"). Mean trophic levels that were not statistically different according to Tukey post hoc tests (homogenous subsets) are marked with a common letter

${ }^{\text {a }}$ Barkley Sound, Vancouver Island, Canada; pectoral muscle; POM ( $\mathrm{TL}=1, \delta^{15} \mathrm{~N}=6.8 \%$ ) (Hobson et al. 1994)

b Northern Gulf of Alaska; pectoral muscle, euphausids $(\mathrm{TL}=2.5$, $\delta^{15} \mathrm{~N}=11.2 \%$ ) (Hobson et al. 1994), Gulf of the Farallones, California, USA; egg albumen; euphausids $\left(\mathrm{TL}=2.5, \delta^{15} \mathrm{~N}=11.2 \%\right.$ ) (Sydeman et al. 1997), North Water Polynya, Canada; pectoral muscle; Calanus hyperboreus ( $\mathrm{TL}=2, \delta^{15} \mathrm{~N}=7.9 \%$ ) (Hobson et al. 2002), coast of Chubut province, Argentina, whole blood, Engraulis anchoita $\left(\mathrm{TL}=3.2, \delta^{15} \mathrm{~N}=16.4 \%\right.$ ) (Forero et al. 2004), Weddell Sea, pectoral muscle, Euphausia superba $\left(\mathrm{TL}=2.2, \delta^{15} \mathrm{~N}=2.3 \%\right.$ ) (Rau et al. 1992)

c Northern Iceland, liver, Mallotus villosus $\quad(\mathrm{TL}=3.2$, $\delta^{15} \mathrm{~N}=10.8 \%$ ) (Thompson et al. 1999)

d Southern Iceland, liver, Mallotus villosus $\quad(\mathrm{TL}=3.2$, $\delta^{15} \mathrm{~N}=10.8 \%$ ) (Thompson et al. 1999)

\section{Penguins}

Penguin feathers are grown shortly after the breeding season, when the penguins come back to perform a complete moult on land. Before the moult, they feed to replenish their body reserves, and the moulted feathers will mainly reflect the diet and foraging range during these feeding trips, in late summer. During this time, the birds are not bound to the colony, as the chicks have fledged, and little is known about their diet and distribution during this time.

The mean $\delta^{13} \mathrm{C}$ values in the three species of penguins were slightly greater than those of squid- and fish-samples, suggesting that they were foraging in waters around the Falkland Islands. Gentoo penguins had a very small range of $\delta^{13} \mathrm{C}$ values, while there was a much larger range in Magellanic penguins and rockhopper penguins, suggesting that in these species, individuals may choose different foraging areas.

Rockhopper penguins had lower $\delta^{15} \mathrm{~N}$ values than Magellanic penguins and gentoo penguins (Fig. 2). The stable isotope values are consistent with studies on diet composition and feeding ranges of the three species at New Island (Thompson 1989; Pütz et al. 2001; Boersma et al. 2002). These characterise gentoo penguins as a mainly fish-feeding species in inshore waters (highest $\delta^{13} \mathrm{C}$ and $\delta^{15} \mathrm{~N}$ values), Magellanic penguins as feeding mainly on squids at an intermediate distance to the shore $(<100 \mathrm{~km})$ (intermediate $\delta^{15} \mathrm{~N}$ values) and rockhopper penguins as feeding mainly on crustaceans either near the shore or far from the colonies (>100 km) (lowest $\delta^{15} \mathrm{~N}$ values). The stable isotope data suggest a substantial overlap in feeding areas between all three species and in TL between gentoo penguins and Magellanic penguins. Conventional diet analyses suggest a high flexibility of diet, as well as possible seasonal changes in all three species (Table 3). This is only reflected in $\delta^{15} \mathrm{~N}$ values of rockhopper penguin and Magellanic penguins, which show large variation, while values of gentoo penguins indicate little variation in diet at least during the pre-moult foraging trips. With a larger sample size, it would be useful to explore interannual differences in diet and foraging areas during the pre-moult foraging trips.

The TLs calculated for gentoo penguins at New Island are similar to those from South Georgia and the South Shetland Islands (Table 4), which is surprising because a diet analysis at South Georgia suggested that a higher proportion of crustaceans was consumed in southern waters (Croxall et al. 1997). No diet information is available for the Kerguelen population, but calculated TL suggests fish to be even more important in this population. However, the high values we obtained from Kerguelen samples (Table 4) are probably an overestimation of the real TL. The higher of the two $\delta^{15} \mathrm{~N}$ values (Table 4) is from a colony that feeds in an enclosed bay (Cherel and Hobson 2007), which may have not been represented by the $\delta^{15} \mathrm{~N}$ value in POM that was used as a baseline for the Kerguelen Islands (Altabet and Francois 1994).

Magellanic penguins breeding at New Island fed at a lower TL than on the coast of Argentina (Table 4). At New Island, small squids rather than fish were the most important prey (Thompson 1989). The high variation of both carbon and nitrogen isotope ratios observed for Magellanic penguins in this study, indicated individual differences and widely scattered feeding areas during the pre-moult period. Individual and sex-dependent differences in diet as reported for the Patagonia population may also be responsible for the high variation (Forero et al. 2002a).

Crustaceans dominated the diet of rockhopper penguins in the Falkland Islands, Crozet Island and the Kerguelen Islands (Thompson 1989, Tremblay and Cherel 2003). This 
Table 3 Diet composition of the focal species from published papers and reports

\begin{tabular}{|c|c|c|c|c|c|c|c|}
\hline Species & Season & Locations & $n$ & Fish $(\%)$ & Squid (\%) & Crust $(\%)$ & Reference \\
\hline GEPE & Oct-Dec 1986 & NI & 16 & 21.5 & 39.4 & 39.1 & Thompson (1989) \\
\hline GEPE & Dec-Feb 1986/1987 & $\mathrm{NI}$ & 27 & 34.3 & 9.3 & 56.4 & Thompson (1989) \\
\hline GEPE & Nov 1987 & $\mathrm{KI}$ & 10 & 25.8 & 24.5 & 49.7 & Thompson (1989) \\
\hline GEPE & $1986-2000$ & FI & 252 & 55.0 & 10.0 & 35.0 & Clausen and Pütz (2002) \\
\hline GEPE & Feb 1986 & SG & 40 & 30.0 & 0.0 & 70.0 & Croxall et al. (1997) \\
\hline ROPE & Nov-Dec 1986 & $\mathrm{NI}$ & 31 & 0.6 & 38.9 & 60.6 & Thompson (1989) \\
\hline ROPE & Dec-Feb 1986/1987 & NI & 32 & 2.2 & 46.4 & 51.4 & Thompson (1989) \\
\hline ROPE & Mar 1987 & $\mathrm{NI}$ & 13 & 14.4 & 78.0 & 7.6 & Thompson (1989) \\
\hline ROPE & $1986-2000$ & FI & 187 & 25.0 & 25.0 & 50.0 & Clausen and Pütz (2002) \\
\hline ROPE & Oct-Nov 1996 & $\mathrm{AI}$ & 34 & 12.2 & 43.9 & 43.7 & Tremblay and Cherel (2003) \\
\hline ROPE & Jan-Feb 1998-1999 & $\mathrm{KI}$ & 36 & 2.9 & 0.0 & 97.1 & Tremblay and Cherel (2003) \\
\hline ROPE & Jan-Feb 1998-1999 & $\mathrm{CI}$ & 27 & 4.3 & 0.6 & 95.1 & Tremblay and Cherel (2003) \\
\hline MAPE & Oct-Dec 1986 & $\mathrm{NI}$ & 12 & 12.4 & 84.1 & 3.5 & Thompson (1989) \\
\hline MAPE & Dec-Feb 1986/87 & NI & 39 & 40.0 & 31.0 & 29.0 & Thompson (1989) \\
\hline MAPE & Nov-Dec 1987 & $\mathrm{KI}$ & 6 & 78.2 & 15.6 & 6.2 & Thompson (1989) \\
\hline MAPE & $1986-2000$ & FI & 282 & 40.0 & 40.0 & 20.0 & Clausen and Pütz (2002) \\
\hline BBAL & Jan-Apr 1987 & NI & 32 & 68.1 & 3.6 & 23.1 & Thompson (1989) \\
\hline BBAL & Jan 1988 & SJ & 20 & 50.9 & 39.6 & 4.4 & Thompson (1989) \\
\hline BBAL & Feb-Mar 1975-1978 & SG & 138 & 38.0 & 20.6 & 39.9 & Prince (1980) \\
\hline BBAL & Feb-Apr 1994-1995 & $\mathrm{KI}$ & 114 & 73.1 & 9.7 & $<0.1$ & Cherel et al. (2000b) \\
\hline WCPE & All months $1984 / 85$ & $\mathrm{BC}$ & 102 & 75.4 & 11.4 & 13.2 & Jackson (1988) \\
\hline WCPE & Feb 1986 & SG & 45 & 16.0 & 25.0 & 59.0 & Croxall et al. (1995) \\
\hline TBPR & Jan-Feb 1987 & NI & 37 & 2.2 & 14.9 & 82.9 & Thompson (1989) \\
\hline TBPR & 1994/1995-1996/1997 & $\mathrm{KI}$ & 85 & 5.7 & 2.9 & 91.3 & Cherel et al. (2002) \\
\hline IMCO & Oct-Dec 1986 & NI & 25 & 18.5 & 11.5 & 70.0 & Thompson (1989) \\
\hline IMCO & Dec-Feb 1986/1987 & NI & 33 & 89.4 & 0.5 & 10.1 & Thompson (1989) \\
\hline
\end{tabular}

All percentage values refer to the part of the fresh mass that could be classified in one of the groups. Species abbreviations as in Table 2 NI New Island (Falkland Islands), KI Keppel Island (Falkland Islands), FI Falkland Islands, SG South Georgia, AI Amsterdam Island, CI Crozet Island, SJ Steeple Jason (Falkland Islands), $B C$ Benguela Current

agrees with the calculated TL for the New Island population, while the TL calculated for birds from the Kerguelen Islands and Crozet Island apparently overestimates the real TL (Table 4). The TL calculated for the population from Amsterdam Island appears too low. The chosen reference value (Altabet and Francois 1994) is apparently not representative for this island. Diet analysis suggests a higher rather than a lower TL for this population (Tremblay and Cherel 2003).

\section{Thin-billed prion}

In comparison with the other species, thin-billed prions forage much further south, as indicated by strongly depleted ${ }^{13} \mathrm{C}$. Thin-billed prions use long and short foraging trips of up to 8 days during the breeding period (Quillfeldt et al. 2007b). During long trips, they reach the waters south of the Antarctic Convergence where foodwebs will have a lower $\delta^{15} \mathrm{~N}$ and $\delta^{13} \mathrm{C}$ baseline value (Altabet and Francois 1994; Best and Schell 1996). The wide scatter of values from thin-billed prion feathers may reflect individuals moulting in areas north and south of the Antarctic Convergence (e.g., Quillfeldt et al. 2008a). As the actual foraging areas of the prions were unknown, and potentially encompass a wide geographic distribution, we could not assign a baseline nitrogen value for this species, and we could not calculate the trophic level of individuals.

White-chinned petrel

Successfully breeding white-chinned petrels moult during the non-breeding season. This species appears to be highly flexible in their diet according to the literature. In the Benguela Current the species was mainly piscivorous (Jackson 1988) and in South Georgia Euphausia superba was the most important prey (Table 3, Croxall et al. 1997). The high TL calculated for the New Island population indicated a high percentage of fish in the diet, consistent 
Table 4 Stable isotope ratios from previous studies

\begin{tabular}{|c|c|c|c|c|c|c|c|}
\hline Species & Age & Seas. & Tissue & $\delta^{13} \mathrm{C}(\%)$ & $\delta^{15} \mathrm{~N}(\% \mathrm{o})$ & $\mathrm{TL}$ & References \\
\hline GEPE $^{\mathrm{a}}$ & Chick & $\mathrm{B}$ & Feather & -23.5 & 7.6 & 3.65 & Quillfeldt et al. (2005) \\
\hline $\mathrm{GEPE}^{\mathrm{b}}$ & Adult male & $\mathrm{B}$ & Blood (cells) & -18.8 & 9.1 & 3.89 & Bearhop et al. (2006) \\
\hline $\mathrm{GEPE}^{\mathrm{b}}$ & Adult female & $\mathrm{B}$ & Blood (cells) & -18.9 & 8.6 & 3.74 & Bearhop et al. (2006) \\
\hline $\mathrm{GEPE}^{\mathrm{c}}$ & Chick & B & Blood (whole) & -18.2 & 11.0 & 4.97 & Cherel and Hobson (2007) \\
\hline $\mathrm{GEPE}^{\mathrm{c}}$ & Chick & $\mathrm{B}$ & Blood (whole) & -15.9 & 12.9 & 5.53 & Cherel and Hobson (2007) \\
\hline $\mathrm{ROPE}^{\mathrm{d}}$ & Chick & B & Blood (whole) & -19.5 & 9.2 & 1.79 & Cherel and Hobson (2007) \\
\hline $\mathrm{ROPE}^{\mathrm{e}}$ & Chick & B & Blood (whole) & -21.2 & 6.8 & 3.44 & Cherel et al. (2007) \\
\hline $\mathrm{ROPE}^{\mathrm{e}}$ & Adult & $\mathrm{B}$ & Blood (whole) & -20.9 & 7.5 & 3.65 & Cherel et al. (2007) \\
\hline $\mathrm{ROPE}^{\mathrm{e}}$ & Adult & NB & Blood (whole) & -19.7 & 7.6 & & Cherel et al. (2007) \\
\hline $\mathrm{ROPE}^{\mathrm{c}}$ & Chick & $\mathrm{B}$ & Blood (whole) & -20.8 & 8.1 & 4.12 & Cherel and Hobson (2007) \\
\hline MAPE $^{f}$ & Adult & $\mathrm{B}$ & Blood (cells) & -16.7 & 18.8 & 4.05 & Forero et al. (2004) \\
\hline MAPE $^{f}$ & Adult male & $\mathrm{B}$ & Blood (whole) & -16.2 & 18.9 & 4.08 & Forero et al. (2004) \\
\hline MAPE $^{f}$ & Adult female & B & Blood (whole) & -16.5 & 18.8 & 4.05 & Forero et al. (2004) \\
\hline MAPE $^{f}$ & Chick & B & Blood (whole) & -16.6 & 19.1 & 4.14 & Forero et al. (2002a) \\
\hline $\mathrm{BBAL}^{\mathrm{c}}$ & Chick & B & Feather & -19.6 & 12.4 & 5.06 & Cherel et al. (2000) \\
\hline $\mathrm{BBAL}^{\mathrm{c}}$ & Adult & NB & Feather & -17.6 & 15.4 & & Cherel et al. (2000) \\
\hline BBAL $^{\mathrm{b}}$ & Adult & NB & Feather & -14.9 & 15.9 & & Phillips et al. (2007) \\
\hline $\mathrm{TBPR}^{\mathrm{c}}$ & Chick & B & Feather & -22.7 & 8.9 & 4.35 & Cherel et al. (2002) \\
\hline $\mathrm{TBPR}^{\mathrm{c}}$ & Adult & NB & Feather & -24.3 & 8.5 & & Cherel et al. (2002) \\
\hline $\mathrm{WCPE}^{\mathrm{b}}$ & Adult & NB & Feather & -15.5 & 17.5 & & Phillips et al. (2007) \\
\hline $\mathrm{IMCO}^{\mathrm{f}}$ & Adult & B & Blood (cells) & -16.3 & 20.0 & 4.4 & Forero et al. (2004) \\
\hline DOGU $^{\mathrm{f}}$ & Adult & B & Blood (cells) & -15.3 & 20.5 & 4.6 & Forero et al. (2004) \\
\hline
\end{tabular}

Note that TLs were calculated from the published $\delta^{15} \mathrm{~N}$ values and were not taken from the original paper. TL were calculated by Eq. 2 with the reference values. NB in the season (seas.) column indicates isotope ratios from the non-breeding season during which the birds location is unknown and hence TL could not be calculated. Species abbreviations as in Table 1

${ }^{a}$ South Shetland $62^{\circ} \mathrm{S}, 58^{\circ} \mathrm{W}$, Euphausia superba, TL $=2.3, \delta^{15} \mathrm{~N}=3.3 \%$ o (Frazer 1996)

b South Georgia $54^{\circ} \mathrm{S}, 38^{\circ} \mathrm{W}$, Euphausids $\mathrm{TL}=2.3, \delta^{15} \mathrm{~N}=4.2 \%$ (Wada et al. 1987)

${ }^{\mathrm{c}}$ Kerguelen Islands, $49^{\circ} \mathrm{S}, 70^{\circ} \mathrm{E}, \mathrm{POM} \mathrm{TL}=1, \delta^{15} \mathrm{~N}=-2.0 \%$ (Altabet and Francois 1994)

${ }^{\mathrm{d}}$ Amsterdam Island $38^{\circ} \mathrm{S}, 77^{\circ} \mathrm{E}, \mathrm{POM} \mathrm{TL}=1, \delta^{15} \mathrm{~N}=7 \%$ (Altabet and Francois 1994)

${ }^{\text {e }}$ Crozet Island $46^{\circ} \mathrm{S}, 52^{\circ} \mathrm{E}, \mathrm{POM} \mathrm{TL}=1, \delta^{15} \mathrm{~N}=-1 \%$ (Altabet and Francois 1994)

${ }^{\mathrm{f}}$ Chubut, Argentina, Engraulis anchoita $\mathrm{TL}=3.2, \delta^{15} \mathrm{~N}=16.4 \%$ (Forero et al. 2004)

with observations of the species to feed on discards from trawlers and bait from longliners on the Patagonian Shelf (Barton 2002). A comparison with the mean isotope values of prey classes also shows fish to be their most important prey. Both carbon and nitrogen isotope values from the South Georgia population (Table 3, Phillips et al. 2007) were remarkably similar to values of adult white-chinned petrels from New Island, suggesting that they both feed in the same area, which is most likely the Patagonian Shelf, during the non-breeding season. The importance of the Patagonian Shelf for the South Georgia population is well documented by satellite telemetry (Croxall and Wood 2002). The high percentage of crustaceans in the diet on South Georgia (Croxall et al. 1997) is not reflected in the $\delta^{15} \mathrm{~N}$ value of New Island adult feathers, while the down of white-chinned petrel chicks had non-significantly lower $\delta^{13} \mathrm{C}$ and $\delta^{15} \mathrm{~N}$ values. Although not significant after
Bonferroni correction, this difference may indicate different feeding areas and a lower TL diet during the breeding season than during adult moult.

High $\delta^{13} \mathrm{C}$ values, similar to those for the adult whitechinned petrels in this study, are found in areas of peak productivity (Francois et al. 1993). During the breeding season, the birds have to trade-off flight distance versus visiting the best feeding areas, whereas in non-breeding seasons they can stay in the most productive areas. This might explain the difference in carbon isotope values between adult feathers and chick down, a difference that is also found in nitrogen isotope values but to a lesser extent. The same pattern is also found in black-browed albatrosses, gentoo penguins and Magellanic penguins. However, as variation for POM isotope ratios were unknown, a seasonal effect reflecting changes in POM carbon isotope values cannot be excluded. 


\section{Black-browed albatross}

The calculated TL for adult black-browed albatrosses is the second highest of the study (Table 1); this result is supported by conventional diet studies in the Falkland Islands and by a comparison with the mean isotope values of prey classes. Fish was the most important prey in those studies (Thompson 1989) and even more important in the Kerguelen Islands (Cherel et al. 2000b). This is also reflected in the calculated TL that was higher in the latter island group (Table 4). Black-browed albatrosses are also known to feed on discards from trawlers (White 1999) and suffer most of all seabirds breeding on New Island from mortalities due to long-line fishing (Barton 2002). At South Georgia, crustaceans comprise a greater proportion of the diet than on New Island (Prince 1980; Thompson 1989). However, as for the white-chinned petrel, this observation was not reflected in the isotope values, and this population may also spend the non-breeding season on the Patagonian Shelf, as indicated by carbon isotope values (Table 4, Phillips et al. 2007) and satellite studies (Croxall and Wood 2002). Our results suggest that black-browed albatrosses and white-chinned petrels show much overlap both in feeding area and diet.

\section{Imperial cormorant}

The New Island population of the imperial cormorant has been found to feed mainly on fish, especially of the genus Patagonotothen, and crustaceans, especially Munida gregaria (Thompson 1989). The calculated TL indicates that fish may be more important during moult (Fig. 2). On the coast of Argentina the species seems to feed at a higher TL (Table 4, Forero et al. 2004). The high $\delta^{13} \mathrm{C}$ value found in the feathers of imperial cormorants indicates that the species mainly feeds in coastal waters, consistent with shipbased surveys in the Falkland Islands (White 1999). A high $\delta^{13} \mathrm{C}$ value is also consistent with less pelagic and more inshore feeding grounds or benthic prey (Hobson et al. 1994).

\section{Dolphin gull}

Dolphin gulls moult during the non-breeding season, and very little is known about their behaviour in the winter period. In summer, the species is a specialised scavenger, feeding on southern sea lion Otaria flavescens excrement and scavenged prey items in colonies of Magellanic penguins and imperial cormorants, and less importantly, on invertebrates in the intertidal zone (Yorio et al. 1996). The low TL indicated by our studies suggests that invertebrates are important in this gull's diet. These may be derived either from scavenging on the faeces sea lions that are depleted in ${ }^{15} \mathrm{~N}$ or from foraging in the intertidal zone (Yorio et al. 1996).

\section{Seabird community studies}

The range of TLs in the seabird communities compared in this study is remarkably similar (Table 2). While there is certainly an effect of species number on the range of TL, all values were in the range 2.8-4.6 and mean values varied only by $0.6 \mathrm{TL}$. The seabird community breeding on New Island had a mean TL at the lower end of the range and significantly lower than the mean value in Patagonia (Table 2). Seabirds in coastal Argentina rely heavily on the abundant small fish Engraulis anchoita while for the birds on New Island crustaceans and small squid are more important (Thompson 1989). The seabird community of New Island may therefore be less vulnerable to direct effects of overfishing than colonies on the coast of Patagonia, and the removal of fish from the ecosystem may even increase the abundance of crustaceans (Lampert and Sommer 1993).

Stable isotope analysis, as applied in most ecological studies, has to deal with the problem of providing only two tracers $\left(\delta^{13} \mathrm{C}, \delta^{15} \mathrm{~N}\right)$ in a system with more than two variables (Cherel and Hobson 2007). The large feeding ranges of many seabirds are particularly challenging. Both $\delta^{13} \mathrm{C}$ and $\delta^{15} \mathrm{~N}$ show large spatial variation that is especially notable near the various frontal systems in the southern hemisphere. Getting good estimates of a species TL can be impossible when it feeds in more than one water mass, as demonstrated by the results obtained from thin-billed prions in the present study. This will be true so long as our knowledge of the spatial and temporal variation of stable isotopes in the ocean remains patchy.

The present study provides baseline carbon and nitrogen stable isotope information for a range of pelagic and coastal seabird species at New Island, collected non-invasively. It demonstrates that the carbon and nitrogen stable isotope values are in good agreement with data from conventional diet analyses, and can be used as a starting point for long-term, non-invasive monitoring.

Acknowledgments We are grateful to the New Island Conservation Trust for permission to work on the island and for providing accommodation and transport. NERC funded the isotope analysis. We would like to thank M. Strange and V. Rösch for contributions to this work. P. Brickle kindly provided fish, crustacea and squid samples, and Paulo Catry contributed albatross down samples. This study was funded by grants provided by DFG, Germany (Qu 148/1-ff) and NERC, UK (Grant-in-Kind EK 82-08/05), and approved by the Falkland Islands Government (Environmental Planning Office). We would like to thank three anonymous referees for their constructive comments. 
Open Access This article is distributed under the terms of the Creative Commons Attribution Noncommercial License which permits any noncommercial use, distribution, and reproduction in any medium, provided the original author(s) and source are credited.

\section{References}

Agnew DJ (2002) Critical aspects of the Falklands Islands pelagic ecosystem: distribution, spawning and migration of pelagic animals in relation to oil exploration. Aquat Conserv 12:39-50

Altabet MA, Francois R (1994) Sedimentary nitrogen isotopic ratio as a recorder for surface ocean nitrate utilization. Global Biogeochem Cycles 8:103-116

Barret RT, Camphuvsen CJ, Anker-Nilssen T, Chardine JW, Furness RW, Garte S, Hüppop O, Leopod MF, Montevecchi WA, Veit RR (2007) Diet studies of seabirs: a review and recommendations. ICES J Mar Sci 64:1675-1691

Barton J (2002) Fisheries and fisheries manamgement in Falkland Islands Conservation Zones. Aquat Conerv 12:127-135

Bearhop S, Waldron S, Votier SC, Furness RW (2002) Factors that influence assimilation rates and fractionation of nitrogen and carbon stable isotopes in avian blood and feathers. Physiol Biochem Zool 75:451-458

Bearhop S, Phillips RA, McGil R, Cherel Y, Dawson DA, Croxall JP (2006) Stable isotopes indicate sex-specific and long-term individual foraging specialisation in diving seabirds. Mar Ecol Prog Ser 311:157-164

Best PB, Schell DM (1996) Stable isotopes in southern right whale (Eubalaena australis) baleen as indicators of seasonal movements, feeding and growth. Mar Biol 124:483-494

Boersma PD, Stokes DL, Strange IJ (2002) Applying ecology to conservation: tracking breeding penguins at New Island South reserve, Falkland Islands. Aquat Conserv 12:63-74

Carabel S, Godinez-Dominguez E, Verisimo P, Fernandez L, Freire J (2006) An assessment of sample processing methods for stable isotope analyses of marine food webs. J Exp Mar Biol Ecol 336:254-261

Cherel Y, Hobson KA (2007) Geographical variation in carbon stable isotope signatures of marine predators: a tool to investigate their foraging areas in the Southern Ocean. Mar Ecol Prog Ser 329:281-287

Cherel Y, Hobson KA, Weimerskirch H (2000a) Using stable-isotope analysis of feathers to distinguish moulting and breeding origins of seabirds. Oecologia 122:155-162

Cherel Y, Weimerskirch H, Trouve C (2000b) Food and feeding ecology of the neritic-slope forager black-browed albatross and its relationships with commercial fisheries in Kerguelen waters. Mar Ecol Prog Ser 207:183-199

Cherel Y, Bocher P, De Broyer C, Hobson KA (2002) Food and feeding ecology of the sympatric thin-billed Pachyptila belcheri and Antarctic P. desolata prions at Iles Kerguelen, Southern Indian Ocean. Mar Ecol Prog Ser 228:263-281

Cherel Y, Hobson KA, Bailleul F, Groscolas R (2005a) Nutrition, physiology, and stable isotopes: new information from fasting and molting penguins. Ecology 86:2881-2888

Cherel Y, Hobson KA, Hassani S (2005b) Isotopic discrimination between food and blood and feathers of captive penguins: implications for dietary studies in the wild. Physiol Biochem Zool 78:106-115

Cherel Y, Hobson KA, Guinet C, Vanpe C (2007) Stable isotopes document seasonal changes in trophic niches and winter foraging individual specialization in diving predators from the Southern Ocean. J Anim Ecol 76:826-836
Clausen AP, Pütz K (2002) Recent trends in diet composition and productivity of gentoo, magellanic and rockhopper penguins in the Falkland Islands. Aquat Conserv 12:51-61

Croxall JP, Wood AG (2002) The importance of the Patagonian Shelf for top predator species breeding at South Georgia. Aquat Conserv 12:101-118

Croxall JP, Hall AJ, Hill HJ, North AW, Rodhouse PG (1995) The food and feeding ecology of the white-chinned petrel Procellaria aequinoctialis at South Georgia. J Zool 237:133-150

Croxall JP, Prince PA, Reid K (1997) Dietary segregation of krilleating South Georgia seabirds. J Zool 242:531-556

Forero MG, Hobson KA, Bortolotti GR, Donazar JA, Bertellotti M, Blanco G (2002a) Food resource utilisation by the magellanic penguin evaluated through stable-isotope analysis: segregation by sex and age and influence on offspring quality. Mar Ecol Prog Ser 234:289-299

Forero MG, Tella JL, Hobson KA, Bertellotti M, Blanco G (2002b) Conspecific food competition explains variability in colony size: a test in magellanic penguins. Ecology 83:3466-3475

Forero MG, Bortolotti GR, Hobson KA, Donazar JA, Bertelloti M, Blanco G (2004) High trophic overlap within the seabird community of Argentinean Patagonia: a multiscale approach. J Anim Ecol 73:789-801

Francois R, Altabet MA, Goericke R, McCorkle DC, Brunet C, Poisson A (1993) Changes in the $\delta^{13} \mathrm{C}$ of surface water particulate organic matter across the subtropical convergence in the SW Indian Ocean. Global Biogeochem Cycles 7:627-644

Frazer TK (1996) Stable isotope composition $(\delta 13 \mathrm{C}$ and $\delta 15 \mathrm{~N})$ of larval krill, Euphausia superba, and two of its potential food sources in winter. J Plankton Res 18:1413-1426

Fry B (2006) Stable isotope ecology. Springer, New York

Glorioso PD (2002) Modelling the South West Atlantic. Aquat Conserv 12:27-37

Hilton GM, Thompson DR, Sagar PM, Cuthbert RJ, Cherel Y, Bury SJ (2006) A stable isotopic investigation into the causes of decline in a sub-Antarctic predator, the rockhopper penguin Eudyptes chrysocome. Glob Change Biol 12:611-625

Hobson KA, Bairlein F (2003) Isotopic fractionation and turnover in captive garden warblers (Sylvia borin): implications for delineating dietary and migratory associations in wild passerines. Can J Zool 81:1630-1635

Hobson KA, Welch HE (1992) Determination of trophic relationships within a high Arctic marine food web using $\delta^{13} \mathrm{C}$ and $\delta^{15} \mathrm{~N}$ analysis. Mar Ecol Prog Ser 84:9-18

Hobson KA, Piatt JF, Pitocchelli J (1994) Using stable isotopes to determine seabird trophic relationships. J Anim Ecol 63:786-798

Hobson KA, Fisk A, Karnovsky N, Holst M, Gagnon JM, Fortier M (2002) A stable isotope $(\delta 13 \mathrm{C}, \delta 15 \mathrm{~N})$ model for the North Water food web: implications for evaluating trophodynamics and the flow of energy and contaminants. Deep Sea Res Part II 49:5131-5150

Hodum PJ, Hobson KA (2000) Trophic relationships among Antarctic fulmarine petrels: insights into dietary overlap and chick provisioning strategies inferred from stable-isotope $\left(\delta^{15} \mathrm{~N}\right.$ and $\delta^{13} \mathrm{C}$ ) analyses. Mar Ecol Prog Ser 198:273-281

Jackson S (1988) Diets of the white-chinned petrel and sooty shearwater in the Southern Benguela Region, South Africa. Condor 90:20-28

Lampert W, Sommer U (1993) Limnoökologie. Georg Thime Verlag, Stuttgart

Mizutani H, Fukuda M, Kabaya Y (1992) $\delta^{13} \mathrm{C}$ and $\delta^{15} \mathrm{~N}$ enrichment factors of feathers of 11 species of adult birds. Ecology 73:13911395

Ogden LJE, Hobson KA, Lank DB (2004) Blood isotopic $\left(\delta^{13} \mathrm{C}\right.$ and $\delta^{15} \mathrm{~N}$ ) turnover and diet-tissue fractionation factors in captive dunlin (Calidris alpina pacifica). Auk 121:170-177 
Phillips RA, Catry P, Silk JRD, Bearhop S, McGill R, Afanasyev V, Strange IJ (2007) Movements, winter distribution and activity patterns of Falkland and brown skuas: insights from loggers and isotopes. Mar Ecol Prog Ser 345:281-291

Post DM (2002) Using stable isotopes to estimate trophic position: models, methods, and assumptions. Ecology 83:703-718

Prince PA (1980) The food and feeding ecology of grey-headed albatross Diomedea chrysostoma and black-browed albatross D. melanophris. Ibis 122:476-488

Pütz K, Ingham RJ, Smith JG, Croxall JP (2001) Population trends, breeding success and diet composition of gentoo Pygoscelis papua, magellanic Spheniscus magellanicus and rockhopper Eudyptes chrysocome penguins in the Falkland Islands. Polar Biol 24:793-807

Quillfeldt P, Masello JF, Strange IJ (2003) Breeding biology of the thin-billed prion Pachyptila belcheri at New Island, Falkland Islands: egg desertion, breeding success and chick provisioning in the poor season 2002/2003. Polar Biol 26:746-752

Quillfeldt P, McGill RAR, Furness RW (2005) Diet and foraging areas of Southern Ocean seabirds and their prey inferred from stable isotopes: review and case study of Wilson's storm-petrel. Mar Ecol Prog Ser 295:295-304

Quillfeldt P, Masello JF, Strange IJ, Buchanan KL (2006) Begging and provisioning of Thin-billed prions Pachyptila belcheri is related to testosterone and corticosterone. Anim Behav 71:13591369

Quillfeldt P, Strange IJ, Masello JF (2007a) Sea surface temperatures and behavioural buffering capacity in thin-billed prions: breeding success, provisioning and chick begging. J Avian Biol 38:298-308

Quillfeldt P, Strange IJ, Segelbacher G, Masello JF (2007b) Male and female contributions to provisioning rates of thin-billed prions, Pachyptila belcheri, in the South Atlantic. J Ornithol 148:367372

Quillfeldt P, Poisbleau M, Chastel O, Masello JF (2007c) Corticosterone in thin-billed prion Pachyptila belcheri chicks: Diel rhythm, timing of fledging and nutritional stress. Naturwissenschaften 94:919-925

Quillfeldt P, McGill RAR, Strange IJ, Masello JF, Weiss F, Brickle P, Furness RW (2008a) Stable isotope analysis reveals sexual and environmental variability and individual consistency in foraging of thin-billed prions. Mar Ecol Prog Ser 373:137-148

Quillfeldt P, Bugoni L, McGill RAR, Masello JF, Furness RW (2008b) Differences in stable isotopes in blood and feathers of seabirds are consistent across species, age and latitudeimplications for food web studies. Mar Biol 155:593-598

Quillfeldt P, Schenk I, McGill RAR, Strange IJ, Masello JF, Gladbach A, Roesch V, Furness RW (2008c) Introduced mammals coexist with seabirds at New Island, Falkland Islands: Abundance, habitat preferences and stable isotope analysis of diet. Polar Biol 31:333-349

Quillfeldt P, Ruiz G, Aguilar Rivera M, Masello JF (2008d) Variability in leucocyte profiles in Thin-billed prions Pachyptila belcheri. Comp Biochem Physiol A 150:26-31

Rau GH, Ainley DG, Bengtson JL, Torres JJ, Hopkins TL (1992) ${ }^{15} \mathrm{~N} /{ }^{14} \mathrm{~N}$ and ${ }^{13} \mathrm{C} /{ }^{12} \mathrm{C}$ in Weddell Sea birds, seals, and fish: implications for diet and trophic structure. Mar Ecol Prog Ser $84: 1-8$

Sommer U (1998) Biologische Meereskunde. Springer, New York

Sydeman WJ, Hobson KA, Pyle P, McLaren EB (1997) Trophic relationships among seabirds in central California: combined stable isotope and conventional dietary approach. Condor 99:327-336

Thompson KR (1989) An assessment of the potential for competition between seabirds and fisheries in the Falkland Islands. Falkland Islands Foundation Project Report

Thompson DR, Lilliendahl K, Solmundsson J, Furness RW, Waldron S, Phillips RA (1999) Trophic relationships among six species of Icelandic seabirds as determined through stable isotope analysis. Condor 101:898-903

Tremblay Y, Cherel Y (2003) Geographic variation in the foraging behaviour, diet and chick growth of rockhopper penguins. Mar Ecol Prog Ser 251:279-297

Upton J, Shaw CJ (2002) An overview of the oceanography and meteorology of the Falkland Islands. Aquat Conserv 12:15-25

Wada E, Terazaki M, Kabaya Y, Nemoto T (1987) ${ }^{15} \mathrm{~N}$ and ${ }^{13} \mathrm{C}$ abundance in the Antarctic Ocean with emphasis on the biogeochemical structure of the food web. Deep-Sea Res 34:829-841

Wanless S, Harris MP, Morris JA (1992) Diving behaviour and diet of the blue-eyed shag at South Georgia. Polar Biol 12:713-719

White RW (1999) Seabird and marine mammal dispersion in the waters around the Falkland Islands: 1998-1999. Joint Nature Conservation Committee, Peterborough

Yorio P, Boersma PD, Swann S (1996) Breeding Biology of the Dolphin Gull at Punta Tombo, Argentina. Condor 98:208-215 